In the opinion of the exhibitors, the Microsporidian parasite, Nosema apis, had been responsible for much of the bee-disease recorded in this country since 1906 , especially in 1906,1907 , and 1911. The exhibitors first noticed the parasite in 1906 in diseased bees obtained from the Isle of Wight; its full significance was grasped in 1907, but owing to the difficulty of obtaining material the exhibitors' results were not published. As much attention was now being directed to " bee-disease," the exhibitors briefly recorded their observations. It was not asserted that microsporidiosis was the only disease of bees current in Great Britain at present, as Dr. Malden had investigated a bacillary infection in bees, the parasite being called Bacillus pestiformis apis. "Foul brood" also was a well-known and separate disease.

Microsporidiosis (due to Nosema apis) had probably been introduced from the Continent into British apiaries.

Other parasites found in bees-chiefly in the gut-by the exhibitors were various species of Gregarines, a Flagellate apparently belonging to the genus Crithidia, a new Amœba (Entamoba apis) very like Entamobci coli of the human intestine, a Spirochæte, and various Fungi.

\title{
PAPERS.
}

29. Contributions to the Anatomy and Systematic Arrangement of the Cestoidea. By Frank E. Beddard, M.A., F.R.S., F.Z.S., Prosector to the Society.

[Received and Read April 4th, 1911.]

('Text-figures 148-159.)

\section{ON some Mammalian Cestoidea.}

I propose to communicate to the Society from time to time reports upon the species of Cestoidea which have been collected, and are being at present collected, from animals which have died in the Society's Gardens. The collection in my hands is the result of nearly two years' examination of (necessarily) a great number of animals, but does not contain as yet a very large number of species, either of known forms or of those which I believe to be undescribed. Tapeworms are by no means so common as other parasitic worms, particularly Nematodes, which are most abundant among the animals in the Gardens. Of the forms which I have identified as belonging to well-known species, I propose at some date to give a complete list, which will be useful, not only as indicating the species which are most abundant in the captive animals, but as extending the range of hosts. At present I could hardly give a long enough list to 
warrant publication in the 'Proceedings.' The new forms, however, I intend to describe, a few at a time, as soon as I can give a sufficiently comprehensive account of their structure to make such publication useful. The present communication contains a fairly full anatomical account of three new species, of

Text-fig. 148.

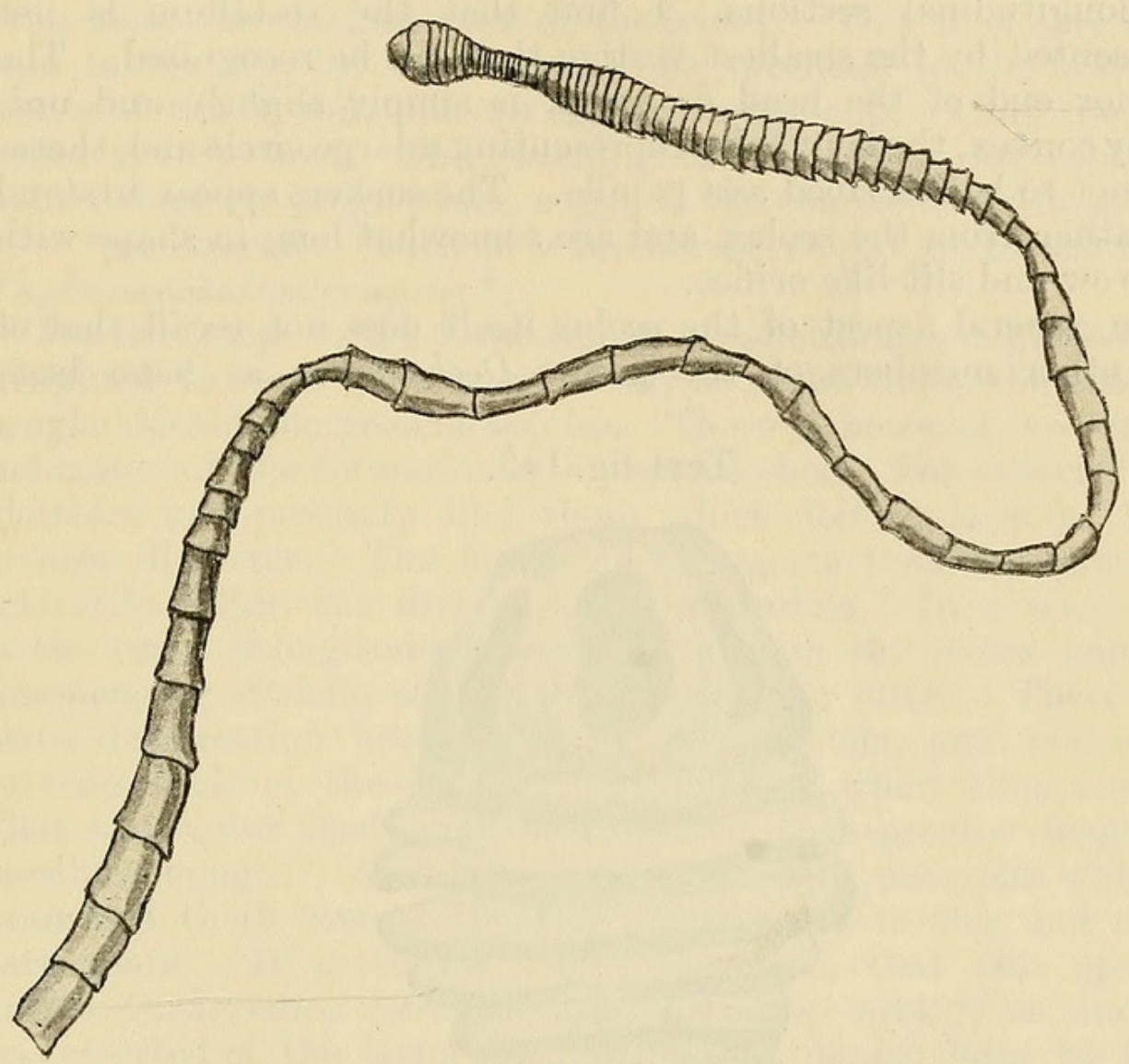

Oochoristica sp., $\times 2$.

two of which I have abundant examples for study. Of the third, I have been able to study two specimens only. But I have been fortunate enough to fill up most of the descriptions which are chiefly required to determine its systematic position with accuracy.

\section{On a Species of Oochoristica.}

I refer a number of individuals from the Lesser Anteater, Tamandua tetradactyla, to this genus, for reasons which will be apparent in the course of the following account of this Tapeworm, and which are summed up at the end of the description in considering its affinities. I believe, however, that the present species is to be regarded as a new one, though it undoubtedly comes very near to Oochoristica wageneri, described by von Janicki from the same Edentate four or five years since*. The reasons for this

* v. Janicki, "Studien an Saügetiercestoden," Zeitschr. f. wiss. Zool. lxxxi. 1906, p. 5. 
opinion will also be given later, after I have detailed the characteristics of these worms.

As is the case with other species of Oochoristica, the scolex of the present species is entirely unarmed and without rostellum. I have studied this and other regions of the body not only by inspection with a lens and the microscope of specimens in spirit mounted entire in Canada balsam, but also by means of transverse and longitudinal sections. I find that the rostellum is not represented by the smallest vestige that can be recognised. The anterior end of the head or scolex is simply slightly and uniformly convex, the convexity representing a large circle and, therefore, not to be described as a papilla. The suckers appear to stand out rather from the scolex, and are somewhat long in shape with a narrow and slit-like orifice.

The general aspect of the scolex itself does not recall that of such other members of the genus Oochoristica as have been

Text-fig. 149 .

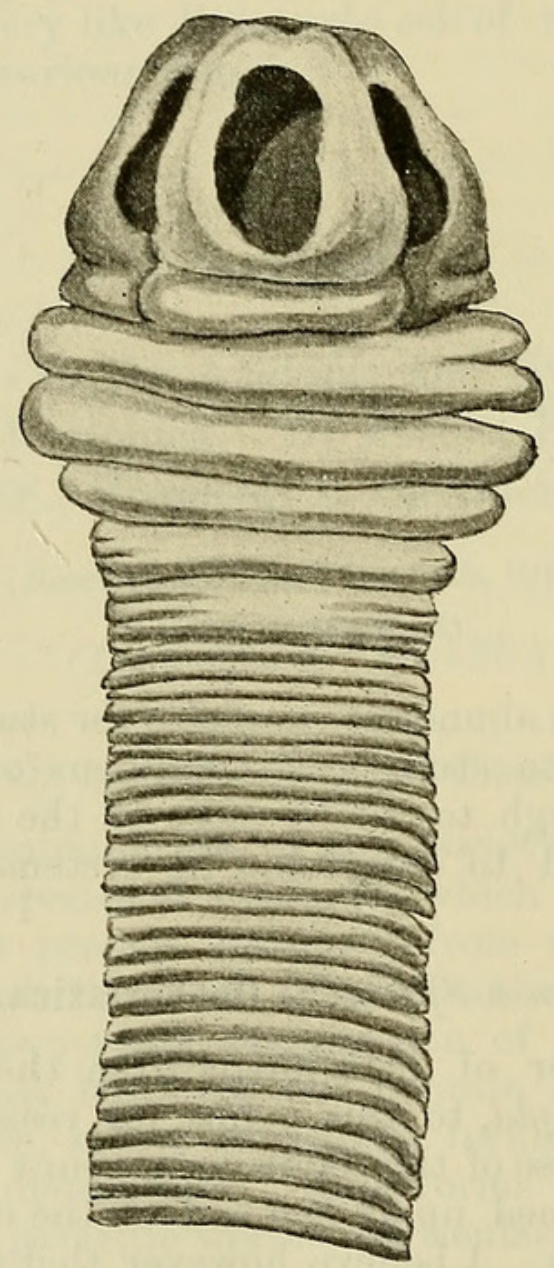

Scolex and a few anterior proglottides of Oochoristica sp.

figured, excepting in its tetragonal form in section. It is, moreover, rather unlike that of other Tetracotylea. When viewed superficially with a lens, or under a low power of the microscope, 
the scolex appears to be of an oval contour, passing thus gradually into a neck, which is at first narrow and later widens out. There is nothing abnormal about the shape of such a scolex. A close examination, however, shows that such a description would be quite incorrect. For the scolex itself is in reality almost semicircular in outline, and its outlines are carried on on either side by the neck of the worm, which is, to begin with, rather wider even than the thickest part of the scolex. This is clearly to be seen in text-fig. 149. It seems to be imbedded in the first segments of the strobila, like an egg in an egg-cup. Thus the true scolex is very short. The widening of the strobila, for a space of some five or six proglottides, suggests the commencing formation of a "pseudoscolex," such as is further developed in, for example, Thysanocephalum crispum* *

The first steps in the formation of a pseudoscolex might well be imagined to occur in some such way as is shown in the anterior proglottides of the present species. There is, however, no further indication of the formation of a pseudoscolex. The anterior proglottides are precisely like those which follow, save in their greater diameter. The figure also suggests that the scolex is retractile within the first part of the strobila. In a sense this is the case. Longitudinal sections through the scolex and the commencing strobila show a bulging of the latter. There is a plain demarcation between scolex and strobila, and not much curving back of the anterior proglottides when thus viewed. That the scolex itself may be extended to a greater length is possible enough. And yet in seven or eight examples which I examined there was an identity of structure in this and other particulars. It is to be noted, therefore, that this species, unlike Oochoristica tetragonocephala, has no neck $\uparrow$, as, indeed, was asserted of the latter by Diesing, but denied later by Lühe and Janicki.

In examining the scolex mounted entire, after clearing with oil of cloves or in alcohol previous to mounting, the suckers are by no means so conspicuous as in other Tapeworms. The slit-like orifice can, indeed, be detected, but it is rather shrouded and dim. The reason for this is apparent when the scolex is studied by means of transverse sections, in which the relations to the head are shown. It will be there seen that, except for the small orifice of the sucker, that organ is not by any means entirely external in situation; the sucker is, in fact, covered by a thickish layer of the ordinary parenchyma of the body. It is thus imbedded in the head, and represents a still further pronounced sessile condition of the sucker, which (inter alia) distinguishes the Tetracotylea from the Tetraphyllidia. At the same time, the sucker retains its cup-like form, the two edges although in

* Cf. Benham in pt. iv. of 'A Treatise on Zoology,' ed. Sir E. Ray Lankester, p. 121, fig. xvii. 2 .

t Unless, indeed, the anterior bulging part of the body of the worm is the neck. But as it shows transverse furrows (text-fig. 149) I do not think that this is the case. 
contact not uniting, thus leaving a slit-like orifice, which is dimly seen when the scolex is viewed in its entirety.

The general aspect of the body is like that of other Tapeworms, in that the anterior region is much narrower than the posterior region, where the segments are in every way larger. In the present worm this distinction is very marked, and the posterior segments are rather more than oval in section, and approach a circular contour. At the same time, this region of the body is much stronger and thicker in every way than the anterior region, so that there is a tendency for this part to become broken off. There seems to be a rather sudden transition between the anterior and the posterior regions. The posterior region of the body, in fact, has quite the contour of an Earthworm, and entirely lacks the flattened appearance of a typical Cestode. The cause of this differentiation is doubtless to be sought in the swelling caused by the dissemination of the ripe eggs through the medullary layer. It is, in fact, in the posterior region that the uteri of the proglottides have entirely disappeared, and are replaced by eggs scattered singly through the parenchyma of the middle layer of the body.

This state of affairs was, however, only to be noted as existing in a marked fashion in the larger and, therefore, presumably more fully mature examples of the worms. Fresh specimens reached about $60 \mathrm{~mm}$. in length, though in none did the breadth of the body exceed $2 \mathrm{~mm}$. Indeed, $1-1.5$ was the prevalent diameter. In smaller worms of $30-40 \mathrm{~mm}$. length, the posterior proglottides were by no means so swollen and remained comparatively flat. So far as can be seen from an examination of the dozen or so of specimens of this worm which I have in my possession, there is no detaching of proglottides. In the first place, I always found the terminal proglottid in its place, and to be distinguished from the others by its oval posterior boundary interrupted by a large orifice (apparently of the water vascular canals) highly suggestive of a proctodœal invagination.

Secondly, the posterior set of segments were not materially different in their form from those preceding them. In those cases where proglottides are shed singly, it is common for them to assume an oval form at the end of the body, and at least to be a good deal constricted at their junctions with each other. There is, commonly, also a very considerable increase of length of the individual proglottides, which favours an easy rupture of their connection. In none of these features do the terminal proglottides of this Oochoristica agree with those of the genera which constantly shed their proglottides singly. Indeed, I have observed that the five or six terminal proglottides are occasionally even shorter than those which immediately lie in front of them. These facts, coupled with the absence of a "neck" where new proglottides are formed, incline one to the belief that the growth of a scolex is limited, and that the whole posterior region dies and liberates the eggs. But of this I have no direct evidence. The relative 
length and-breadth of the proglottides differ in different regions of the body and in individuals. A small example $(30 \mathrm{~mm}$. in length) mounted in two pieces in Canada balsam showed the following characters of strobilisation. The diameter of the wider posterior region of the body was not more than three times that of the narrowest part of the neck. I made out in all 167 strobila, and there were not, I am convinced, many more. The first 42 were very short, being very much broader than long. After this point the diameter of the worm became greater, and the segments, therefore, larger; they appeared to be longer in proportion to their breadth; but the first 31 of the series were, I believe, not so. From this point, however, to the end of the body the length of the segments was proportionately a little greater. But throughout the series the actual breadth was really considerably greater than the length. In a second specimen, of which the head end only was mounted, the state of strobilisation presented quite a different appearance. The first 45 segments or so were quite as in the last specimen; but after this point the length grew very rapidly in proportion to the breadth, and in a few segments no measurements were needed to assist the eye in seeing that the proglottides were very much longer than broad. A careful examination of these elongated segments showed that the broader hind margin which overlapped the narrower anterior section of the ensuing segment was regularly crumpled, showing a series of regularly arranged projections, and in the middle of the segment these were represented by alternate furrows and elevations. This looks very much like the effect of a muscular pulling out of a segment from end to end. But in any case this variability in the proportions of individual proglottides shows that it is a difficult matter to define Tapeworms very accurately by the proportions of length and breadth of the proglottides in different regions. The instances given would appear to be those of proglottides which had been unduly lengthened through pulling longwise. But I have observed instances of the contrary. In some proglottides from the middle of the body there was a marked transverse wrinkling, a kind of division of the segment into annuli, which shows from a different point of view how difficult it is to rely upon the relative dimensions of proglottides as aids to the definition of a species or of a genus, as the case may be. It is certainly quite unsafe in the case of this Oochoristica.

Before proceeding to the consideration of the internal organs, there is one other external feature that requires description, namely, the orifices of the generative ducts. These are alternate, but not regularly so. The openings are, however, as a rule, preponderatingly upon one side of the body. Thus in a portion of one worm I found two pores consecutively upon one side of the body. The next was on the opposite side; the five following reverted to the first state, and the last examined showed again an alternation. In another specimen, from another worm, there was one pore on one side, followed by three consecutive pores on the 
other side; then came two on the opposite side to these, and then two on the opposite side to the two last described. These instances will be sufficient to illustrate the general facts. It is quite possible that the proglottid which first shows these openings may vary from individual to individual. In any case a careful examination of a small individual mounted in two pieces upon a slide, and whose strobilisation has been already described above, showed no generative ducts in front of proglottid 113 or so. It will be remembered that this worm had a limited number of proglottides altogether, there being not many, if any, more than 167. In this particular case it was not difficult to ascertain accurately the point at which the ducts began. For, where present, they were extremely conspicuous through staining, and the cells composing the conjoined ducts formed a rather thick mass. And I am, therefore, sure that they did not exist, except perhaps in small rudiments, before the 113th proglottid. It was easy to ascertain that the gonads themselves-at any rate, the ovaries - existed anterior to this segment. Furthermore, these facts are still further supported by the condition of a second specimen which had been cut into longitudinal sections up to about the same point of the body. Here, too, the generative ducts did not exist much anteriorly to the 113th segment-if, indeed, at all anteriorly. The actual pores were only clearly visible upon more mature proglottides, and were quite conspicuous round orifices near to the anterior border of the proglottid.

The excretory vessels would seem from the figures of Janicki to be very characteristic of the genus Oochoristica, for in the species figured by him there are additional lateral vessels varying according to the species. I have found the same thing in the species of Oochoristica which I describe in the present paper. The conditions, however, seem to vary somewhat in different regions of the body. Anteriorly there are eight, longitudinally running, which in the very anterior and therefore very thin segments are almost in the same plane, and therefore can be seen in a single longitudinal section. Further back the eight tubes are differently arranged. There are two nearer to the middle line and dorsal, according to Janicki*, and two ventral more widely separated. The two lateral tubes on each side are less markedly dorsal and ventral respectively. In posterior segments I could see only six longitudinal vessels, as is represented in textfigure 150 , of which the four median were placed alternately with regard to each other, and not as in earlier segments.

The gonads are visible in sections rather early in the body. I found them without any trouble in the rather wider segments which follow immediately upon the anterior sixty or so segments which form the anterior section of the chain of proglottides. A somewhat leaf-shaped mass of cells, the apex directed posteriorly, and which represents presumably the yolk-gland as well as the 
ovaries, reaches from near to the anterior boundary of the proglottid to beyond the middle of a segment. The testes occupy a restricted area in the posterior region of the segment, and I observed in these young proglottides something like 20 or 30 of them. They are not in contact with the ovaries, but, like them,

Text-fig. 150 .

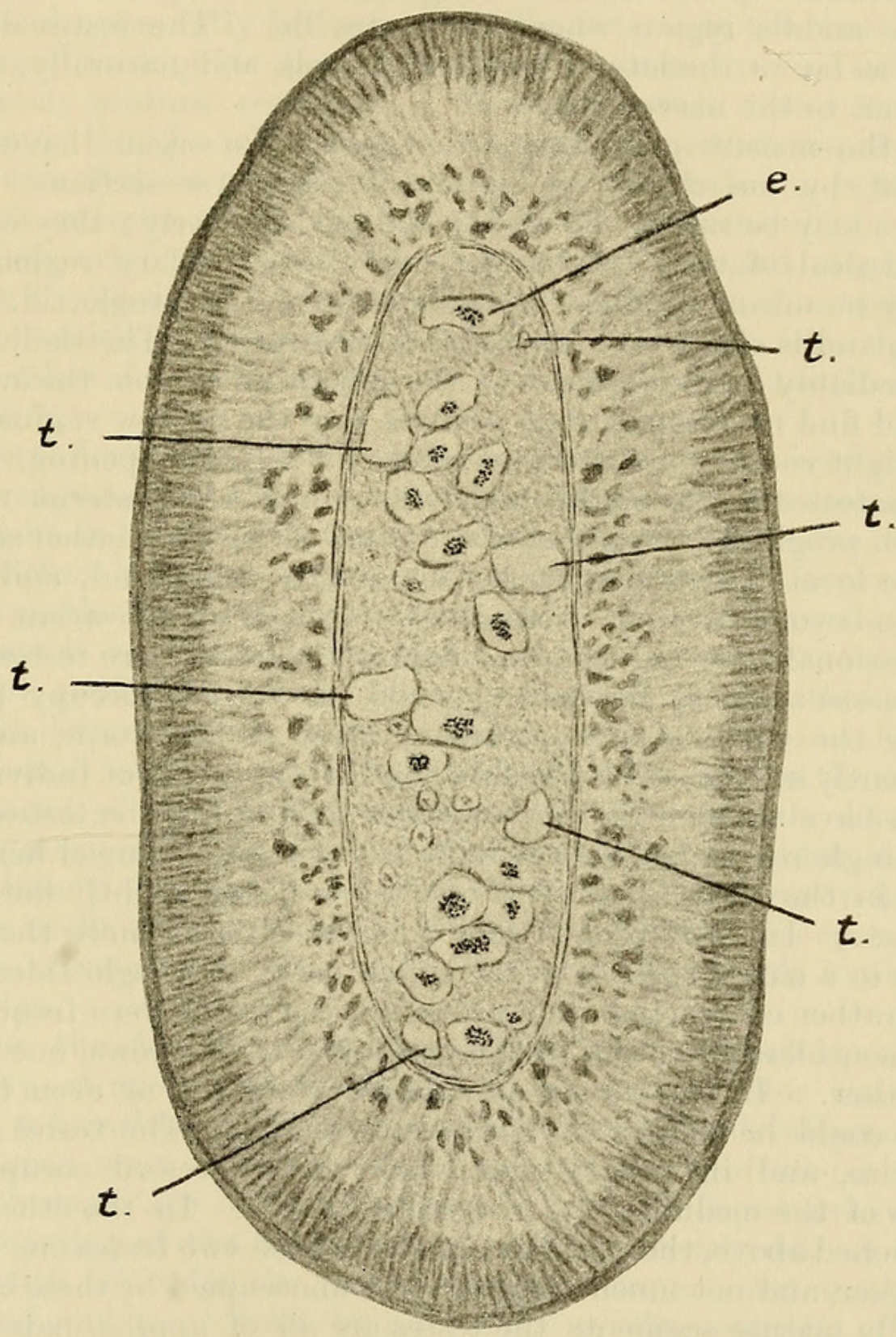

Transverse section of a posterior segment of Oochoristica sp., showing scattered embryos embedded in general parenchyma.

$e$. Embryo. $t$. Longitudinal trunks of water-vessels.

are median in position. I occasionally observed also 2 or 3 testes on one side of the ovary. Further back, when the genital ducts first appear, the testes still form a mass which is chiefly posterior 
to the ovary, but which has also to some extent grown round the sides and lies laterally of the ovary.

Examining, as an entire object stained and preserved in balsam, some segments at about the same stage of development as those last referred to, it will be noticed that the small and numerous testes occupy in their extension from side to side of each proglottid about half of each proglottid. The lateral areas not invaded by the testes are together about equal in diameter to the middle region where the testes lie. The testes do not reach as far as the lateral excretory vessels, and naturally, therefore, not to the nerve-cord.

In the mature proglottides the generative organs have been studied by me chiefly by means of transverse sections. The ovaries may be said to be double and lie anteriorly; they occupy a good deal of the available space in the medullary region, and are by no means confined to the middle of the proglottid. The yolk-gland is single and lies behind the ovaries. The shell-gland lies medianly in the segment on the opposite side from the ovaries. I could find no receptaculum seminis, and the narrow vagina runs a straight course for some way before its external opening.

The testes in the mature segments occupy the posterior region of each proglottid ; but they also extend forward on either side up to the level of the anterior border of the yolk-gland, and even a little beyond, so that in transverse section some ovarian tissue is occasionally seen in the same field with one or more testes. In transverse sections, the male gonads are seen to occupy pretty nearly the whole of the medullary layer of the worm, and are frequently in contact with each other. In segments of individuals which have apparently been stretched during life the testes were in a single row only dorsoventrally, or, at most, arranged here and there in the form of a "W," one testis being slightly dorsal of another. In such proglottides I never counted more than ten testes in a single row. On the other hand, in proglottides that were rather contracted than extended, the testes were frequently for a considerable extent of the proglottid in two rows, one above the other. In such cases as many as fourteen or even fifteen testes could be seen in one transverse section. The testes are of fair size, and in proglottides which are depressed occupy the whole of the medulla from above downwards. In the other case mentioned above, the medulla accommodated two testes one above the other, and not much room was left unoccupied by these bodies. In fully mature segments the testes are all of approximately the same size, and there must be some fifty or so in a single proglottid. It is easy to trace a thin membrane surrounding each testis, and completely shutting it off from the parenchymatous tissue of the medulla from neighbouring testes. This is the state of affairs that we find in fully mature segments, in which, however, there is as yet no scattering of the eggs in the parenchyma, such as occurs in the terminal segments of the body. In a young specimen mounted entire, the testes were quite plain in certain anterior segments of 
the body, wherein the genital ducts had not attained their full development. In such a segment the testes are seen to be distinctly more numerous than in such segments as have just been described, a transverse section would show fully twenty testes in a given plane (in the region of the proglottid where they are most abundant). At the same time, these gonads are much smaller. I have sections of proglottides which show an intermediate state of affairs, and in which the posterior testes are large and apparently full-grown, while anteriorly the testes are very small and quite similar to those of immature or only incompletely mature segments. These immature testes had no membrane that I could detect. It appears to me that the advance in growth of these gonads is achieved by the inclusion within a common membrane of areas of testicular growth which have separately originated and which in the very youngest stages can be seen to consist of a single cell only. It will be observed that the disposition of the testes of this species is quite like that of some other forms belonging to this genus as described by Janicki ${ }^{*}$.

Several fortunate sections have enabled me to see very clearly the arrangement of the vas deferens and its mode of termination. This tube is loosely coiled not far from its entry into the cirrus sac. Before it enters the latter it passes in a straight course and enters at the very extremity of the sac. It is noteworthy that this duct is quite double the width of the vagina at its opening into the genital cloaca and for some distance behind this point. 'The vas deferens when it enters the cirrus sac at once swells out into a small vesicula seminalis, which thus lies within the cirrus sac instead of outside as in most cases. The vesicula does not by any means fill even the end of the cirrus sac in which it lies. Immediately after this the duct narrows again, and again immediately swells out into a smaller dilatation. After this comes the narrow cirrus itself. The walls of the cirrus sac are loose and muscular.

Liihe, the founder of this genus, in some notes $\uparrow$ upon the anatomy of species of Oochoristica from Lizards (for example, Tania tuberculata of Rudolphi), remarks that the development of the uterus must be extraordinarily rapid, as so often no intermediate stages are obvious between a fully developed ovary and the scattering of the mature eggs in the parenchyma. I quite agree with Liihe, for the reason that the uterus is not always to be found and is at least by no means so characteristic of this particular Tapeworm as it is of many others. There are, however, stages to be observed. I have never seen more than a small elongated sac lying near to either the ventral or the dorsal side of the segment. In longitudinal sections this sac shows a tubular form, and is, indeed, so narrow a tube that on first observing it I mistook it for one of the excretory vessels, and imagined that the

* Zeitschr. f. wiss. Zool. lxxxi. 1906.

† " Oochoristica nov, gen. Tæniadarum," Zool, Anz. xxi. 1893, p. 650. 
gonads were passed to the exterior through those tubes. However, the uterus is actually present in this form.

From the above account of the external characters and internal anatomy of this worm we may deduce the following brief résumé:-

Length 30-60 mm., diameter $1 \mathrm{~mm}$.-2 $\mathrm{mm}$. Posterior region of the body markedly differentiated in fully adult examples by its great thickness, but anterior end not so thin as in many forms. Terminal segment with deep slit-like depression always present. Scolex unarmed with rudimentary rostellum. Suckers unarmed and sunk within the head, which is tetragonal in section. No neck, segmentation beginning at once; the anterior five or six proglottides wider than scolex and seeming to form a hood into which it can be partly retracted. Proglottides variable in proportions of length to breadth. In many examples all of them, save the last few, broader than long. In others some of anterior segments longer than broad. Dorsal and ventral excretory canals not parallel, the two dorsal being nearer together than the two ventral; in addition to these, two lateral narrower canals on each side. Cortical layer as thick as medullary. Genital pores alternate irregularly, the preponderance being on one side, near to anterior border of proglottid. Testes numerous, posterior to and at the sides of ovary. Ovaries in anterior part of proglottid commencing shortly after anterior border. Genital ducts pass between dorsal and ventral water tubes. Vas deferens coiled; no obvious seminal receptacle or seminal vesicle. Uterus sac-like, with branches; ultimately disappearing, the eggs being imbedded singly in the parenchyma. Occasionally traces of uterus in form of sacs containing two or three ova persist.

$H a b$. Small intestine of Tamandua tetradactyla.

We may now consider the systematic position of this Cestoid. The lateral position of the genital pores, the unarmed scolex, the four suckers without appendages or hooks, the anterior position of the cirrus pouch, the absence of more than a suggestion of a pseudoscolex, show that this worm is to be referred to one of the three families Anoplocephalidæ, Hymenolepididæ, or Tæniadæ, of Ransom's systematic table * (which is with slight differences the same as that of Fuhrmann + ). From many of the numerous genera contained in the first two of these families and the very few genera of the last, the present worm is to be differentiated by the following assemblage of characters:- scolex unarmed, no neck; genital organs one set to each proglottid, with irregular pores; testes numerous, posterior in position ; uterus disappears ; eggs imbedded singly in parenchyma.

The characters of the worm rather suggest the Anoplocephalidæ, particularly, of course, the unarmed scolex and the absence of a " neck." But there is no genus in this family to which it can be referred. The nearest is Linstowia, in which the genital pores are alternate, the eggs are imbedded singly, and the cortical layer

* Bull. U.S. Nat. Mus. no. 69, 1910.

+ Zool. Jahrb. extra vol. x. 1908. 
of the body is thick. But in Linstowia the testes extend throughout the proglottid, the genital ducts pass ventrad of the excretory vessels, and there are other differences. Of the Hymenolepidr the following genera only have an unarmed seolex and a single set of generative organs with alternate pores, viz., Catenotcenia, Oochoristica, Rhabdometra, Anonchotcenia, Metroliasthes, and Nematotcenia. Nematotcenia may be set aside as only showing strobilisation posteriorly. In Anonchotcenia the testes are anterior and the eggs finally pass into a paruterine organ. In Rhabdometra and Metroliasthes the testes are posterior and at the sides of the ovary, and the genital canals pass between the excretory vessels as in the species which forms the subject of the present communication ; but in those genera, as in Anonchotcenia, there is a paruterine organ into which the eggs finally pass. There remain, therefore, by this process of exclusion only Catenotcenia and Oochoristica. The former genus must be eliminated, since the genital ducts pass dorsad of both excretory tubes* and the uterus is persistent. The present species is therefore to be referred to a new genus or is to be included in Oochoristica. More recent information about this latter genus than was available to Ransom when he drew up his table shows - what is, indeed, also apparent from that table-that the worm with which I have occupied myself is an Oochoristica and does not need a new genus for its reception. Ransom's definition is: "Scolex unarmed, without rostellum. Single set of reproductive organs in each segment. Genital pores irregularly alternate. Testicles numerous, surrounding female glands posteriorly and on the sides. Vas deferens coiled; seminal vesicle absent. Uterus breaks down early and eggs become enclosed singly in egg capsules." I shall now deal with the question of the species to which these worms should be referred.

So far as I am aware, only two Tapeworms have been described from the gut of Tamandua tetradactyla. The first of these is Tania tetragonocephala of Bremser, described by Diesing $\uparrow$, and later, as well as more fully, by Lühe $\ddagger$, whose description disagrees in several particulars with that of Diesing. The most important external disagreement concerns the scolex, which is represented by Diesing as having no neck, while Lïhe finds a neck $2 \mathrm{~mm}$. long. This is obviously a matter of some importance; and I am inclined therefore to regard the Tapeworm described here by myself as not identical with T'.tetragonocephala for that reason alone. With the general anatomical description added by Lühe to Diesing's account the worms studied by myself fully agree, and are clearly of the same genus which Janicki § more recently has shown to be Oochoristica. Janicki's memoir contains also additional facts

* This point is not referred to by Ransom in his definition of Oochoristica; I have not accidentally omitted it.

† Denkschr. k. Akad. Wien, xii. 1856.

+ Arch. f. Naturg. 1895, p. 199.

$\S$ Zeitschr. f. wiss. Zool. lxxxi. 1906, p. 524. See also Zschokke, "Das genus Oochoristica," $i b$. vol. lxxxiii.

Proc. Zool. Soc.-1911, No. XLV. 
upon the anatomy of $O$. tetragonocephala, which confirm my opinion that the species examined by myself is not the same. In particular, I refer to the much more complicated excretory vessels, which are illustrated by a text-figure *

The second species inhabiting the gut of Tamandua tetradactyla is Oochoristica wageneri of Janicki, who had, however, only a single not very well-preserved example to work upon. Unfortunately one very important point, as I think it, viz., the condition of the neck, was not ascertained, and, as I understand, could not be ascertained by Janicki from the imperfection of his specimen. There are some other points in which my specimens were not identical with that described by Janicki. He described ripe proglottides as longer than unripe ones. But this is not always the case in my specimens, since I have found quite early in the strobila long segments. But the examination of other examples might have led Janicki to alter this statement. For, as I have myself shown, there is some variation in the form of the proglottides in different regions of the body and in different examples. I have noted in describing the excretory tubes certain differences from the apparently regularly arranged six tubes found in $O$. wageneri; but here, again, it is possible that the examination of more material would have shown that these differences do not exist.

On the other hand, I am disposed to see differences in the uterus in the two forms. Janicki describes that organ in O. wagener $i$ as an irregular sac lying anteriorly in the segment and extending back as far as or beyond the ovaries, and gives a figure showing this arrangement. The uterus in my examples was much more irregular, and here and there, as I have described, were quite tubular portions of it.

Even in the very last segment of the body, which might be supposed to be fully mature, the uterus had by no means quite disappeared in all specimens, although the majority of the eggs were strewn through the parenchyma, as Janicki states to be the case in his species, and as is characteristic of the genus. In other respects I can find no differences between the facts as I read them and Janicki's descriptions. I do not, therefore, from a consideration of all the facts, come to the conclusion that the present species is certainly distinct from $O$. wageneri, but that equally it is not certainly identical with it. Since we know that two undoubtedly different species are found in the Edentate Tamandua, there is no a priori reason against the existence therein of a third or even of more species of this genus. I prefer, therefore, in view of these doubts, to give no name to the worm which is here described.

\section{Bertiella cercopitheci, sp. $n$.}

An example of the Green Cercopitheque, Cercopithecus callitrichus, which died in the Society's Gardens in February 1911, contained two examples of a Tapeworm, which were found,

* Loc. cit. p. 535, fig. 5 . 
contrary to what is more usual, in the colon and not attached to the walls of that gut. It may be, therefore, that the parasites had been loosened from their attachment in the small intestine and had drifted into the colon, of which portion of the alimentary tract they are therefore not really inhabitants. However, both specimens were quite alive and exhibited writhing movements, and it is possible therefore that they are really parasitic in the colon. They were of about the same size, and shrunk considerably on preservation in alcohol. One of the two specimens, which I have preserved entire and regard as the type of the species, measures in the alcoholic condition $150 \mathrm{~mm}$. It is remarkable for the extreme shortness and great width of the segments, and agrees in this particular with species of the genus Bertiella, of which other anatomical characters prove it to be a member.

The anterior extremity (as is shown in text-figure 151) is very minute, and the body gradually widens up to a diameter of some $10 \mathrm{~mm}$. Its general appearance is thus not precisely, although it is generally, like that of other species of this genus. Accompanying the increase in width of the proglottides there is also an increase in thickness, and the posterior end of the body is about 2-3 $\mathrm{mm}$. thick. In addition to the two specimens of the worm there was a detached piece, possibly of one of these, of about an inch in length. It appears to me that, as in Bothriocephalus, for example, the proglottides are not shed singly but in groups. The head of the worm is black in parts, the arrangement of the pigment being peculiar, as I shall describe shortly. This black-headed condition suggested to me that we might be dealing here with examples of P. van Beneden's Tania melanocephala* , a parasite from another species of African Monkey. The other characters given by van Beneden are in perfect harmony with this view of the identity of the species, but, as Blanchard $\uparrow$ has pointed out, the characters given are really not enough to determine the genus to which Tania melanocephala belongs, let alone the species.

Nor does my discovery here recorded of a black-headed Tapeworm found in an African Monkey, and clearly referable to the genus Bertiella, in any way settle the point at issue. For, in the first place. I have found in a species of Davainea (or, at any rate, an allied genus) the same distribution of the pigment in the head that will shortly be described in the species now under consideration ; so that the mere presence of pigment in the head is clearly no criterion of the identity of the worm. In the second place, another species of Bertiella, viz. B. mucronata, also from a monkey, has been described $\ddagger$ in which the head is likewise pigmented. It will be shown later that my species is not Bertiella mucronata. Moreover, there is no reason, owing to the defective description of van Beneden, for the identification of $B$. melanocephala with B. mucronata. Thus it is necessary, as I think, to give $\varepsilon$ new name

* Mém. sur les Vers intestinaux, Paris, 1859, p. 162.

† Mém. Soc. Zool. France, 1891, p. 186.

‡ Meyner, "Zwei neue Tænien aus Affen," Zeitschr. f. Naturw. 1895, p. 1. 
to the present species, in spite of the fact that it may prove ultimately to be identical with Bertiella melanocephala.

In any case, I shall be arlding some further facts to the general anatomy of the genus by the following account of this form.

Text-fig. 151.

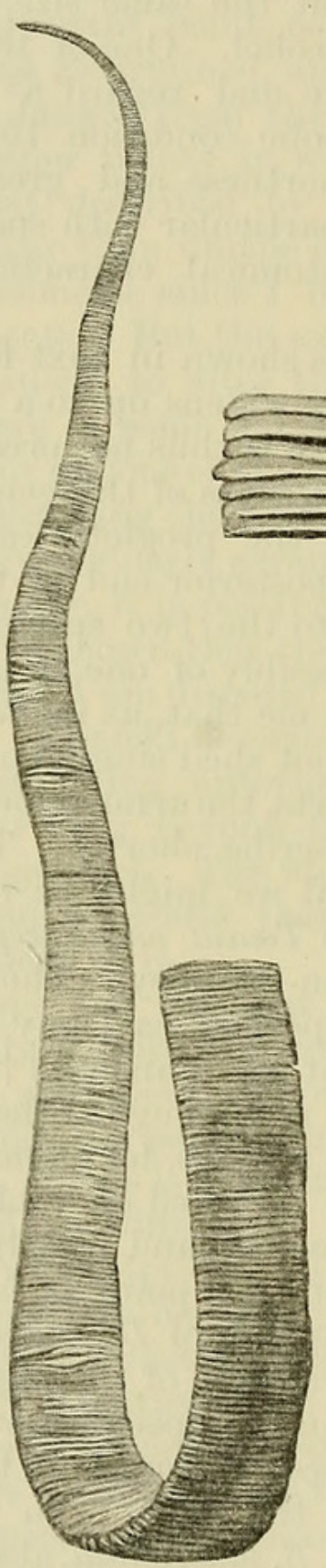

Bertiella cercopitheci, nat. size.

A few of the posterior segments are shown more highly magnified.

The head is rather narrower than the ensuing body, in which the proglottides are evident from the very first, there being thus no neck. In the two specimens which I have examined, the suckers presented different conditions. In one they were apparently 
absent altogether, being really retracted almost completely within the head; there were four little tags only protruding from the anterior extremity. This scolex I have examined further by transverse sections. The second worm showed only two cup-like suckers, with their cavity directed upward as in other species of Bertiella. One of these is distinctly larger than the other, and

Text-fig. 152.

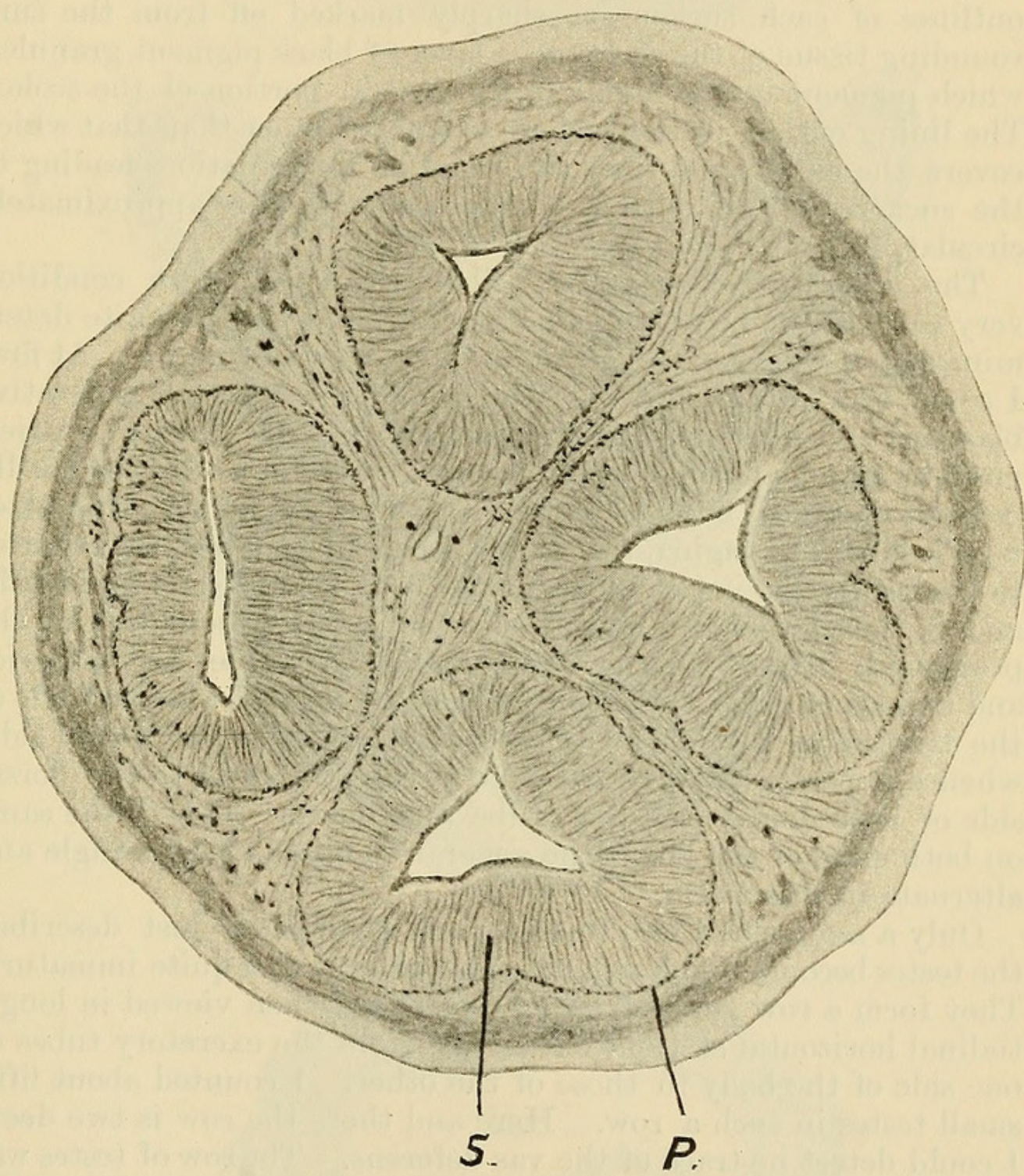

Bertiella cercopitheci.

Transverse section through scolex.

S. Sucker. P. Pigment-sheath of the same.

I presume that the remaining two were completely retracted within the head. In a series of very nearly accurately transverse sections through the head of the first individual, the earliest sections showed four equidistant grooves lined by a continuation of the thick cuticle of the scolex, which expanded towards the 
middle of the interior of the scolex into oval chambers lined by an equally thick cuticle. Further down the canals lost their connection with the exterior and were $\mathbf{T}$-shaped, with still a very thick cuticular lining and no recognisable sucker structure. This canal in each of the four quarter's of the scolex continued for some sections without any change, and then the suckers themselves became plainly visible, being thus entirely retracted within the scolex and removed from the exterior. The cavity of the suckers is here triangular, with the sides closely pressed together. The outlines of each sucker are sharply marked off from the surrounding tissue of the scolex by a layer of black pigment granules, which pigment is also found in the central portion of the scolex. The lining cuticle of the suckers is much thinner than that which covers the scolex, and lines the canal of invagination leading to the suckers. The outline of the scolex is here approximately circular.

The generative organs are visible in an immature condition very early in the body, though I have not made an accurate determination of the exact segment in which they first occur. At first I could find no trace of any testes, simply a mass of generative blastema which occupies the position of the future ovaries, vitelline gland, and shell-gland, from which leads a solid rod hardly narrower towards but not to the edge of the proglottid; this latter is, of course, the vagina, \&c. This mass of tissue lies just anterior to the transverse vessel, uniting the two ventral excretory vessels, and is therefore some way from the posterior boundary of the proglottid. In transverse sections through these very anterior and immature proglottides it is seen to lie upon the ventral side of the transverse vessels and to cross it obliquely to the dorsal side, whence it passes towards the edge of the proglottid to the dorsal side of both dorsal excretory tube and nerve. This is the same on both sides of the body, the generative organs being single and alternate in this worm.

Only a segment or two further back than those just described the testes become visible, though, of course, at first quite immature. They form a row generally only one deep (when viewed in longitudinal horizontal section) extending from the excretory tubes of one side of the body to those of the other. I counted about fifty small testes in such a row. Here and there the row is two deep. I could detect no trace of the vas deferens. The row of testes was anterior to the rudimentary female organs. These latter are by this time somewhat more developed. They still present, however, a perfectly straight line, but reach very nearly to the edge of the proglottid. There is, however, no external aperture. The fact that the vagina is a tubular formation is beginning to be evident, and the shell-gland, with radiating cells, in which it ends is plain; the ovary and vitelline gland lie below it and thus not in the same plane with the vagina.

The female organs extend over more than a quarter, but not quite a third, of the diameter of the proglottid. In still later proglottides the uterus is for the first time quite visible and can 


\section{Text-fig. 153.}
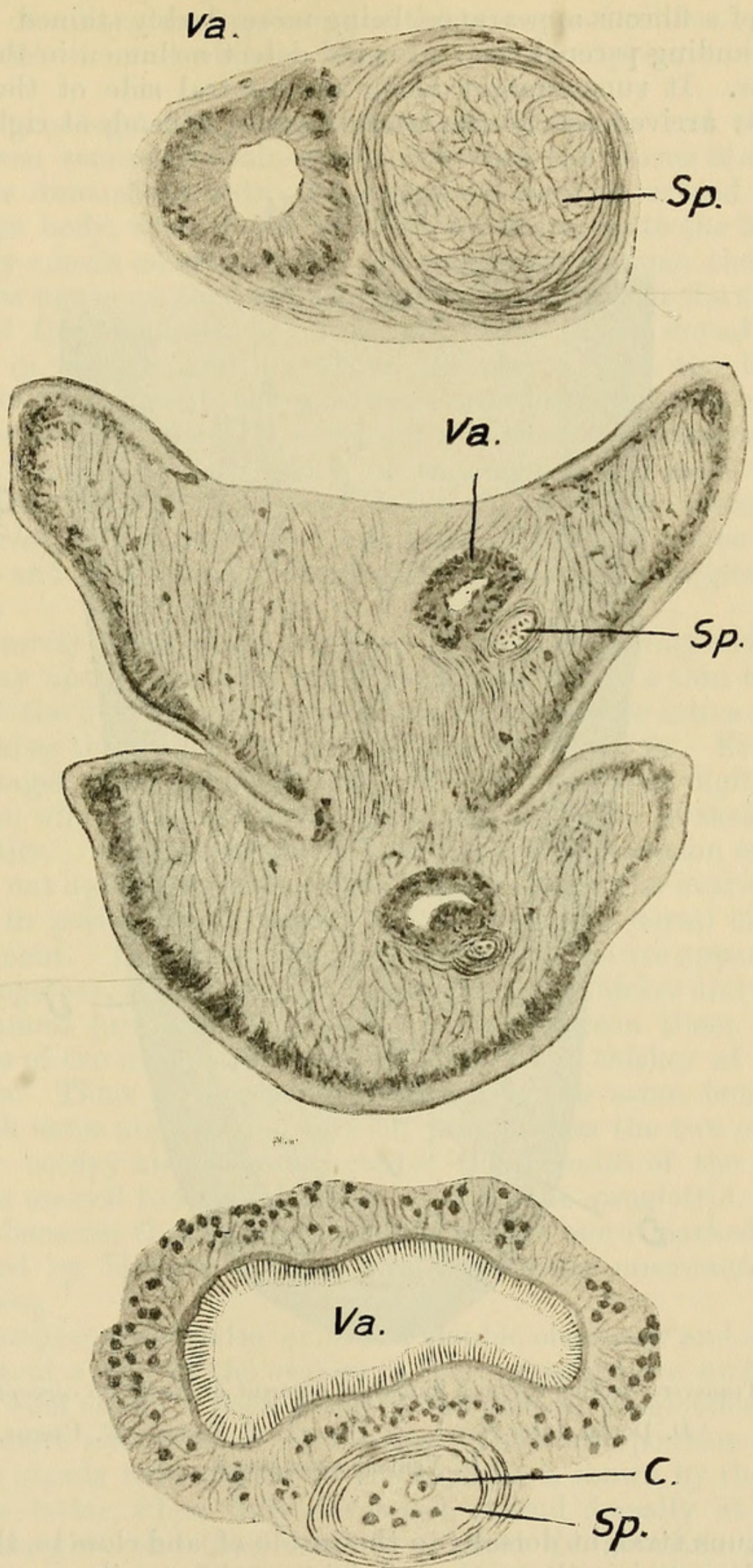

Bertiella cercopitheci.

Section s through sperm-duct and vagina at three points near to their external orifices, to illustrate relative position and structure.

C. Cirrus. $S p$. Sperm-duct. $V a$. Vagina. 
be traced for a considerable distance either way as a solid cord of cells of a fibrous appearance, being more darkly stained than the surrounding parenchyma. I could detect nolumen in this young uterus. It runs straight along the ventral side of the row of testes ; arrived near to the lateral vessels, it bends at right angles

Text-fig. 154.

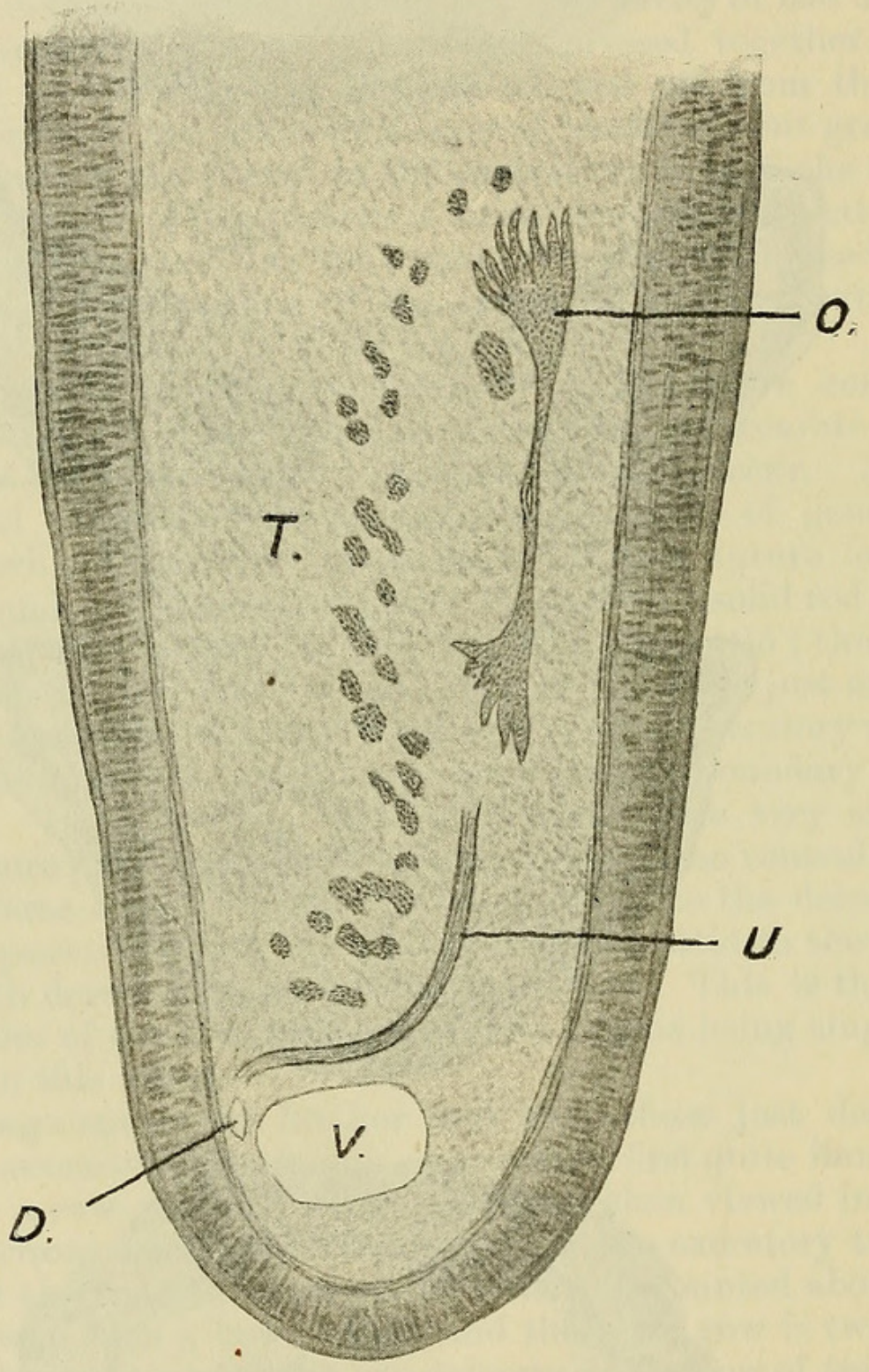

Transverse section through immature segment of Bertiella cercopitheci.

$D$. Dorsal water-vessel. $O$. Ovary. $T$. Testes. $U$. Uterus.

$V$. Ventral water-yessel.

and runs straight dorsally to the inside of, and close to, the watervessels, crossing the vagina at right angles on its way. I could not ascertain definitely the opening of the sperm-duct into the cirrus sac which lay parallel with and dorsally to the vagina. Nor could I see any branches running from the sperm-duct to the 
individual testes at any point. It is for this reason that I regard the cord of cells as the beginning of the uterus and not as a spermduct, which it undoubtedly suggests in its appearance and position.

In mature segments, when both the vas deferens and the receptaculum seminis contain sperm, but when the uterus is still of moderate dimensions only, the testes are seen to extend right across the body, when there is room for them, up to the lateral excretory vessels on either side. In transverse sections they are seen to be not more than two or possibly three deep in the middle region of the proglottides. They are rather more dorsal than ventral in position and are above the uterus. In the lateral regions of the segments they are more crowded and often rather closely pressed together. I could not find that the testes existed outside of the medullary region of the segments, a point which I mention particularly, since Meyner $*$ met with testes (in $B$. conferta) which had traversed gaps in the transverse musculature and had taken up their position among the longitudinal muscles.

The ovaries in the young proglottides are quite distinct and even some way apart from each other, being joined by a thin bridge which is the oviduct and which dilates in the middle into a round sac marking the point of junction of the two oviducts. Even in young stages the ovaries are divided into numerous digitiform processes, which are not in the young stages thicker at their free extremities. These processes radiate out from a common centre, fanning out away from each ovary respectively. The ovaries are ventral in position and radiate out towards the dorsal side of the segment. In mature proglottides the ovaries are apparently nearer together, that is, the connecting bridge is thicker and forms a continuous junction of germinal tissue between them. The processes of the ovary are now club-shaped, i.e. thicker at their free ends. Their arrangement is otherwise the same, but they are much more numerous. In such proglottides the two ovaries together occupy about one-quarter of the breadth of the body. They are massed towards the pore side of the proglottid. The double character thus remains distinct and is more marked than is figured by Meyner for his species Bertiella mucronata and B. conferta.

The vitelline glands also exhibit a double character and are to some extent a copy of the ovaries in their general form and relations to each other. Each gland in the mature proglottides lies a little above and between the ovaries. The dorsal position of the vitelline glands with regard to the ovaries is shown by the fact that the latter, when fully developed, extend dorsally at their lateral margins and thus come to encircle the vitelline glands lying between them. Each vitelline gland is lobate, with numerous oval lobes tending towards a club shape radiating out from a 
common centre, there being thus a likeness to the ovaries. The two glands are likewise united by a bridge of tissue. Both the ovaries and the vitelline glands are in close contact with the walls of the receptaculum seminis. The shell-gland lies again rather dorsally to the vitelline glands; but here the growth of those glands laterally causes the shell-gland to lie rather between than above the vitelline glands. It is in close relation with the median end of the receptaculum seminis, which does not extend beyond it.

The sperm-duct in the mature proglottides has a form apparently like that of other species of Bertiella parasitic in Monkeys, and is not to be distinguished, so far as I can see, from that of Bertiella mucronata. The sperm-duct is of considerable width from the very first, i. e. where it emerges from the cirrus sac. It is probable, however, that this region is really to be looked upon as representing the vesicula seminalis of other Cestodes. A part of this dilated sperm-duct lies actually within the cirrus sac as is depicted for Bertiella polyorchis by v. Linstow. This portion, which is quite short, is wider than the section which follows. The latter, however, is also wide and lies in pretty regular coils of three alongside the vagina as far as the commencement of the wide receptaculum seminis. It is gorged with sperm and its walls are thin, but very plainly recognisable by their dark staining. The coiling commences directly after the emergence of the sperm-duct from the cirrus sac, and we have therefore here a coiled region of the sperm-duct which corresponds to that characteristic of many other Tapeworms, but with the addition that it is the vesicula seminalis part of the sperm-duct which is coiled.

The sperm-duct appears to come to abrupt conclusion at about the commencement of the wide receptaculum seminis. But in favourable sections it may be traced further as a very slender tube closely adherent to the ventral wall of the receptaculum. In the posterior segments of the body, which are distended with ova, the sperm-ducts do not degenerate; on the contrary, they are somewhat larger than in the first mature segment. They contain, moreover, more sperm, which has somewhat distended them: the walls thus appear thinner. The ducts in this region of the body lie quite as coiled as in the more anterior proglottides ; it might be supposed that they would be straightened out by the tension caused by the enclosed spermatozoa. Nor has the spermduct in any way shifted from the normal position, lying, as it does, alongside of, and in close contact with, the vagina, which has undergone in this region of the body considerably greater alterations. The same triple arrangement of the coils is visible - that is to say, in a given transverse section there are usually three tubes to be seen, this being, of course, the expression of the coiling.

The vagina of this species is specialised into several regions, as it is shown to be in B. mucronata and B. conferta in the figures of Meyner. The proglottides, from an examination of which I have compiled the following description, appear to be in much the same stage of sexual development as those figured by 
Dr. Meyner*, for which reason, of course, I have selected them. The terminal region nearest the external pore has a thick muscular sheath and the lumen is narrow. This section widens abruptly

Text-fig. 155.

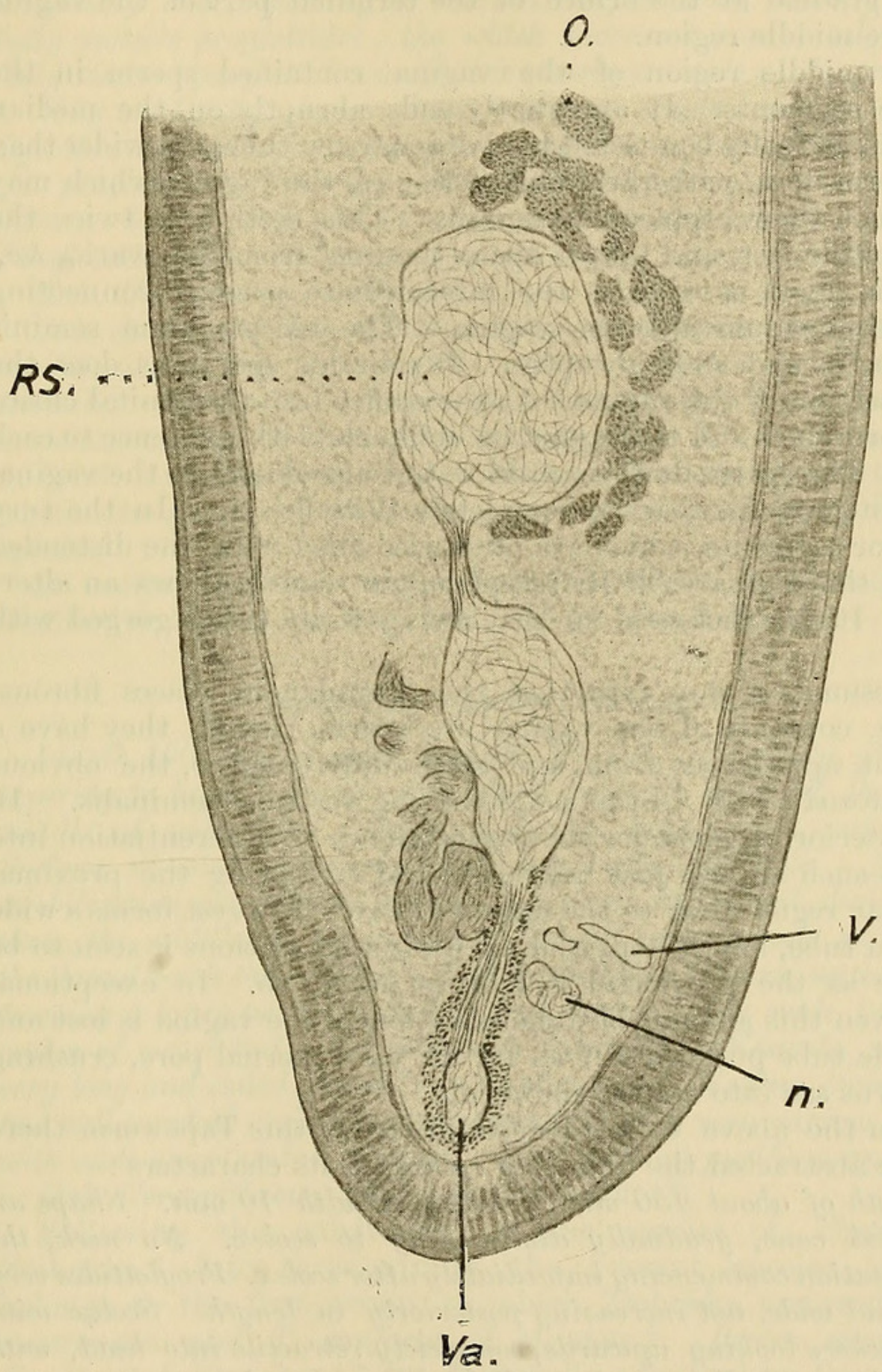

Transverse section through mature segment of Bertiella cercopitheci.

$n$. Nerve-cord (only one of the three strands visible). O. Ovary. RS. Receptaculum seminis. $V$. Ventral water-vessel. $V a$. Vagina, to the left of which is seen the dilated and coiled sperm-duct.

* Loc. cit. pl. i. fig. 3, pl. ii. fig. 9 . 
into a thin-walled and much wider section, the muscular walls of which are not more than, if so much as, half of the diameter of those of the previous section. The transition is not regular, as is figured by Meyner in the two species examined by him. The diminution in thickness of the muscular layer, however, is rather gradual at the orifice of the terminal part of the vagina into the middle region.

This middle region of the vagina contained sperm in the mature segments. It apparently ends abruptly on the median side, but is really connected by a very narrow tube, not wider than the sperm-duct, with the distal section of the vagina, which may be termed the receptaculum seminis. This section is twice the width of the last, and into it opens the duct from the ovaries \&c., which is about as wide as the intermediate passage connecting the receptaculum and the vagina. The receptaculum seminis thus begins and ends abruptly. It contains sperm, as does the distal section of the vagina. At the orifice into the genital cloaca the sperm-duct and the vagina lie obliquely with reference to each other. The sperm-duct is anterior, but also dorsal to the vagina, and a little further back is completely dorsal to it. In the very posterior segments, which are otherwise filled with the distended uterus, the vagina with its receptaculum seminis shows an alteration. It has increased in size, owing to its being gorged with sperm.

I presume, at any rate, that the granular, in places fibrouslooking, contents of the vagina are sperm, though they have a different appearance from, and stain differently to, the obvious spermatozoa which fill the neighbouring vesicula seminalis. In the posterior proglottides the vagina shows no differentiation into regions such as have just been described, excepting the proximal muscular region near to the external pore. The rest forms a wide uniform tube, and in longitudinal horizontal sections is seen to be as wide as the proglottid is long or nearly so. In exceptional cases even this amount of differentiation in the vagina is lost and the wide tube pushes itself as far as the external pore, crushing the cirrus sac into a mere rudiment.

From the above detailed description of this Tapeworm there may be abstracted the following résumé of its characters :-

Length of about $150 \mathrm{~mm}$., greatest breadth $10 \mathrm{~mm}$. Shape an elongated cone, gradually diminishing to scolex. No neck, the strobilisation commencing immediately after scolex. Proglottides very short and wide, not increasing posteriorly in length. Scolex with four suckers looking upuards, completely retractile into head, with black pigment. No armed rostellum. Dorsal and ventral excretory tubes at first subequal, later the ventral very much the larger; the two tubes are superposed dorso-ventrally, with a transverse trunk connecting the two ventrals. Genital pores alternate, frequently with regularity. Generative ducts dorsal to water-vessels and nerve. Testes numerous, forming a layer two or three thick, reaching completely between water-vessels, anterior and dorsal in position. Cirrus feeble, no sperm-sac (vesicula seminalis). Sperm-ducts 
open to side and in front of vagina and pass back along ventral margin of rows of testes. In fully mature segments sperm-ducts increase in volume. Ovaries double, ventral and posterior in position, in front of transverse excretory vessel, formed of numerous club-shaped masses radiating from common centre. Vagina unusually wide, showing a marked receptaculum seminis in less fully mature proglottides; the width increases enormously in the fully mature proglottides until it is nearly as wide as the proglottid is long. Genital cloaca short. Uterus single, sac-like, without definite outgrowths, but somewhat irregular in form, filling most of the proglottid. The eggs without $\mathbf{V}$-shaped apparatus, with a thinner inner shell and a very wide and lax outer membrane. Proglottides apparently not detached singly, but in groups.

Hab. Cercopithecus callitrichus.

It is clear from this definition that the Tapeworm now under consideration has been rightly referred by me to the genus Bertiella. There is, I think, no other genus which shows the same assemblage of characters as those which $I$ have just set forth in brief. It remains to be seen what position the species occupies within the genus, of which we now know a good many different species.

It seems that we may select the following characters as distinctive of this species, which will be thus definable :-

\section{Bertiella CERCopitheci, sp. $\mathrm{n}$.}

Length $150 \mathrm{~mm}$. or more, breadth $10 \mathrm{~mm}$. posteriorly, gradually tapering to head. Scolex with black pigment scattered throughout middle of scolex and forming a special layer round each sucker. Suckers directed anteriorly, and completely retractile. No neck, strobilisation commencing at once. Lateral nerve-cord divided into three, the middle one the largest. Lateral water-vessels superposed, the dorsal much the smaller. Testes extending between water-vessels, forming a layer two or three deep and three or four wide in middle region of proylottid, more numerous laterally. Vesicula seminalis very long and coiled, extending into cirrus sac. Vagina divisible into two well-marked regions and communicating by very narrow interval with wide receptaculum seminis. Eggs without pyriform apparatus.

Hab. Cercopithecus callitrichus, in colon (?).

Following the subdivision of the species of Bertiella by Zschokke* into three groups, the present species evidently belongs to the first group, to which Zschokke assigned Taenia mucronata and $T$. conferta of Meyner $\uparrow$. Bertia studeri and $B$. satyri of Blanchard $\ddagger$ are doubtfully admitted by Braun $\S$ into the genus Bertiella as recognised by the better-known species fully described by Meyner, for Blanchard does not describe the genital

* "Neue Studien an Cestoden aplacentaler Saügethiere," Zeitschr. wiss. Zool. lxv. 1897, p. 404.

+ “Zwei neue Tænien aus Affen," Zeitschr. f. Naturw. 1895, p. 1.

+ Mém. Soc. Zool. France, 1891, p. 186.

$\$$ Bronn's Klassen u. Ordn. des Thierreich, iv. Abth. 1 B, p. 1712. 
organs, except in so far as to remark upon their alternating pores and upon the structure of the ova. Nor does he say anything of the pigmentation of the head, which is so marked a feature of my species and of the otherwise unrecognisable Tania melanocephala of van Beneden*.

B. mucronata was described from an American Ape, Mycetes niger, and I gather from Meyner's description that the Tapeworms themselves were brought from Paraguay, and thus real inhabitants of the Monkey in question, which, therefore, had not been infected in a menagerie. This species shows the same pigmentation of the head as mine, and its general shape $\uparrow$ is not very different. Nevertheless, it appears to me that in the species described in the present paper the anterior end is more tapering, and has a very small diameter for a longer stretch. Indeed, the general outline of the worm described in the present paper is more like Meyner's B. conferta $\ddagger$, which is, moreover, a parasite of an Old World Monkey, Macacus radiatus, and therefore, perhaps, more likely on à priori grounds to be identical with mine. I think, however, that B. conferta may be put out of court in this comparison, for the reason that no mention is made of a black pigmentation in the scolex, which is so clear a feature of my species and of $B$. mucronata. Nevertheless, $B$. conferta agrees with my species and differs from $B$. mucronata in that the vagina enters the receptaculum suddenly, there being no gradual widening. as in $B$. mucronata, where the tubes are continuous. The suckers are said, however, to be lateral in position, as in B. mucronata $\$$. This is one of the principal reasons which lead me to regard my species as distinct. Of B. mucronata Meyner writes:- "Sind nicht vollständig nach vorn, sondern mehr zur Seite gerechtet." In a series of transverse sections through B. cercopitheci, which I have described above, it is very clear that the apertures of the suckers are not lateral nor slit along the retracted sucker, such as is so obvious in the other species described in the present paper.

Nor does Meyner describe the remarkable pigment-sheath to each sucker which characterises my species. Furthermore, it appears that B. mucronata has a "neck" ; for Meyner writes |: "Schon etwa $0.9 \mathrm{~mm}$. vom Skolexscheitel entfernt, also in einem Stadium, wo der Körper noch keine Spur einer Gliederung erkennen lässt, gruppiren sich," etc. Stiles, in reviewing 9 the characteristics of this species, points out that B. mucronata is also to be defined by the fact that the generative canal passes to the exterior between the nerve-cord on the one hand and the two excretory vessels on the other. My sections of B. cercopitheci show very plainly that the generative canal passes dorsally to both nerve and lateral excretory vessels. This is particularly

* Mém. sur les Vers intestinaux, Paris, 1859.

+ Loc. cit. pl. i. fig. $1 . \quad \pm$ Loc. cit. pl. ii. fig. 8 .

§ In other Bertiella (e.g. in Sluiter's B. plastica, see Centralbl. Bakt. xix. 1896, p. 941) the suckers look upwards.

|| Loc. cit.p. 81.

- Proc. U.S. Nat. Mus. 1896, p. 145. 
obvious in young proglottides, which are so slender that the disposition of these structures can be seen in a single section.

A final point of systematic importance concerns the horn-like processes of the innermost egg-shell, which are figured by Meyner and stated by him to be always very obvious. I have been absolutely unable to detect these structures, even when using an oil immersion-lens ( $\frac{1}{12}$ in. Leitz). We must, therefore, agree that this group of species of Bertiella is to be characterised, as the two remaining groups into which Zschokke divides the genus, by " birnförmiger Apparat nicht constant." I am unable to compare the species which I describe here as Bertiella cercopitheci with two species described by Gottheil * from Macacus cynomolgus and from that species and Cebus capucinus, since they are not sufficiently diagnosed, and Stiles is of opinion that they are only doubtfully to be referred to the genus Bertiella. Indeed, the position of the genital pores is not referred to.

Another Monkey parasite with which my Tapeworm might be compared is v. Linstow's Bertiella polyorchis † from Macacus cynomolgus. This is interesting, from the point of view of the eggshells, and confirms what I have said above concerning the absence of the horn-like processes in B. cercopitheci; for it is hardly likely that so experienced a helminthologist as Dr. von Linstow would have overlooked these structures were they present, and his figure of the egg of $B$. polyorchis does not show them. Furthermore, the suckers look forward and a dilation of the sperm-duct within the cirrus sac is figured. The species, however, differs, as I believe, from Bertiella cercopitheci by its less complicated vagina, by the much greater number of testes which fill the middle of the proglottid, and by the absence of any black pigmentation in the head. At any rate, the latter point is not referred to.

\section{Thysanosoma gambianum, sp. n.}

I obtained from an example of the Gambian Pouched Rat, Cricetomys gambianus, which died in June 1909, a considerable number of Tapeworms which I regard as being of a new species and belonging most probably to the family Anoplocephalidæ. The Rodent had been one year and ten months in the Society's Gardens before its death, and it is, therefore, quite credible that it was infected with these Cestodes when it arrived in London. The material, as well as being abundant, was well preserved, and I am therefore able to give a fairly comprehensive account of the anatorny of the species, which presents certain new combinations of characters.

The external characters alone appear to place this worm in either the genus Anoplocephala or Zschokkeella. There are no other genera in which the scolex is unarmed, the genital pores are unilateral and the neck is absent, and the segments until the

* Journ. Comp. Med. \& Surgery, 1887, vol. vii. The species are not named and are referred to Tania.

† Arch. f. Naturg. lxxi. 1905, p. 270. 
very end of the body are broader than long. Unilateral genital pores occur only in these two genera among the subfamily or family Anoplocephalidæ or Anoplocephalinæ. There are, however, several genera among the remaining Tetracotylea which possess genital pores in sequence upon one side only. But the number of genera is small and other external characters prevent a confusion. Thus the Tapeworm which forms the subject of the present section cannot be confused with Aploparaksis, Diorchis, Gryporhynchus, Paruterina, Culcitella, Oligorchis, Lateriporus, Dilepis, Davainea, Progynia, Idiogenes, Chapmannia, Proorchida, Monopylidium, or Cyclorchida, since all of these have a circle or more than one circle of hooks upon the rostellum. There remains Hymenolepis, which is to be distinguished by

Text-fig. 156.

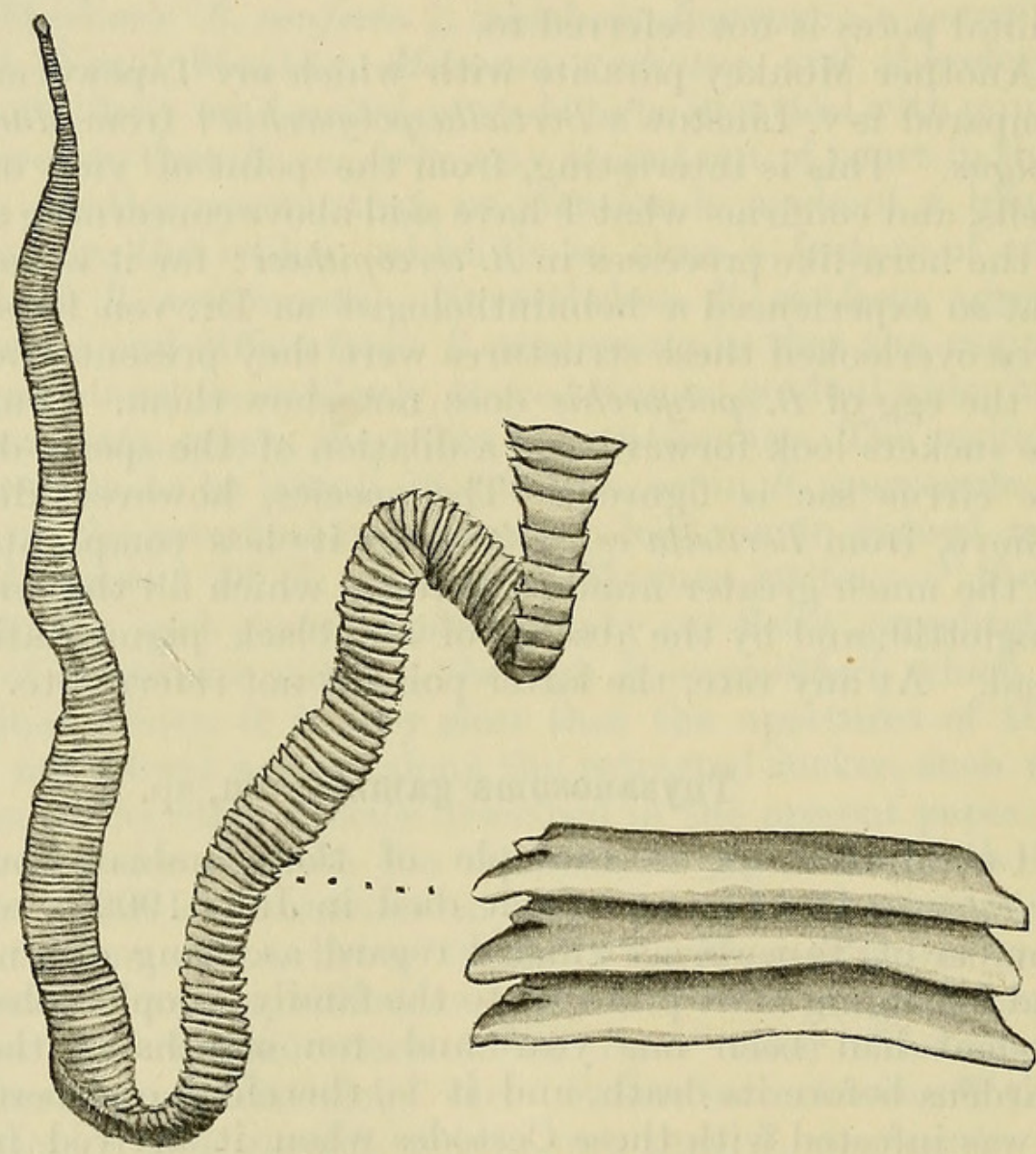

Thysanosoma gambianum, nat. size.

To the right are a few segments more highly magnified to show genital papilla.

possessing a "neck," which the present species does not, and by the limited series of testes in each proglottid. I am thus correct, as I believe, in regarding this worm as a member of the Anoplocephalidæ.

There are reasons both for and against referring the Tapeworm from the Gambian Pouched Rat to either of these genera or to a new genus, into which I shall enter at length after detailing its anatomy. This species is a large worm, measuring 
some 6 inches in length. A very marked characteristic is the fact that the segments are wider than long throughout almost the whole of the body. It is only at the extreme end that they become longer. The segments overlap successively, so that it is possible to detect the anterior margin of each segment. The worm is not very stout, but flattened after the typical Tapeworm fashion; the most posterior segments alone being rather thicker in a dorso-ventral direction. The diameter of the body in the middle is some $6 \mathrm{~mm}$. There is no marked colour, though, as will be seen presently, there is some internal pigmentation. The general character of the segmentation suggests that the proglottides are not shed.

This species like Anoplocephala has no "neck," as it is termed, that is to say, there is no undifferentiated zone following the scolex,

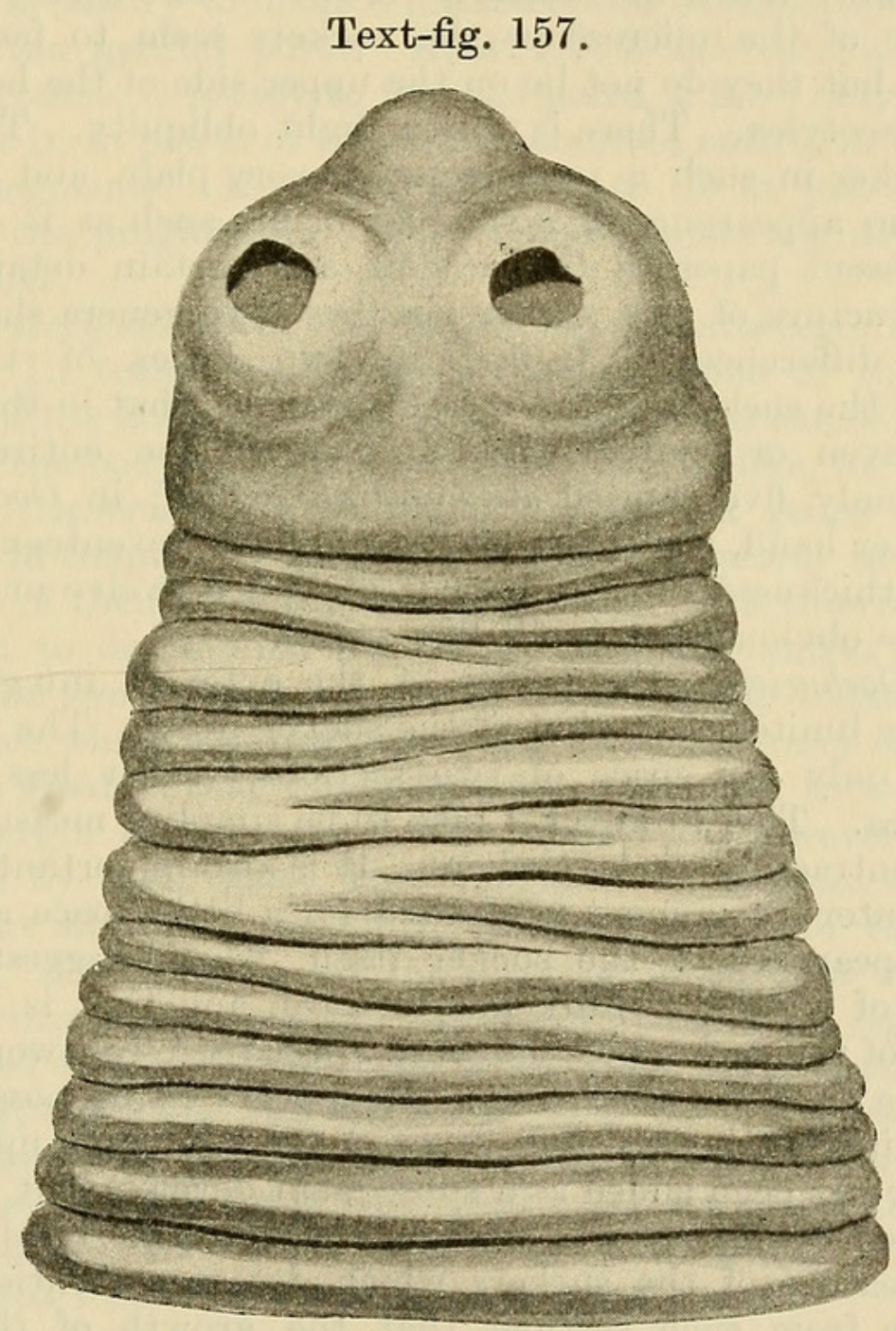

Scolex of Thysanosoma gambianum.

where the limits of the proglottides are unrecognisable. The definite proglottides are obvious from the very first. They are at first rather narrower than they become posteriorly; but the diameter of the body very soon attains to its full dimensions.

Proc. Zool. Soc.-1911, No. XLVI. 
The cirrus of each segment is not visible, or at least not conspicuous, when the worm is viewed with a lens, in a protruded condition. This is due to the small size of these organs, which will be more fully described later. I have not found it possible to differentiate the ventral from the dorsal surface. The scolex, as already stated, is unarmed. I investigated this part of the worm by the section method, and am therefore able to state positively that there is no rostellum nor any trace of hooks. Nor do the suckers show any hooks that I could detect. I am convinced that they are absent altogether from the scolex of this worm. A regular series of transverse sections across the "head" shows a rostellar region above the region of the suckers, which is oblong in section; it contains no pit or depression of any kind that was obvious to me. The suckers are the usual four and as usual symmetrical. When the scolex is viewed in its entirety under a low power of the microscope the suckers seem to face rather upwards; but they do not lie on the upper side of the head as in some Tetracotylea. There is only a slight obliquity. The orifice of the sucker in such a preparation is very plain and rounded. There is no appearance of a slit-like orifice such as is described in the present paper in Oochoristica, and certain details in the minute structure of the suckers in these two genera show corresponding differences. I find in two series of transverse sections of the suckers of the two Tapeworms, that in the present species eleven or twelve sections displayed the entire sucker, of which only five showed its cup-like orifice; in Oochoristica, on the other hand, the entire sucker required seventeen sections of equal thickness for its display, of which twelve or thirteen showed the obviously more slit-like orifice.

As in Oochoristica the orifice of the external integument is much more limited than that of the sucker itself. The two coincided for only the space of two sections, rather less than in Oochoristica. This, however, I take to be simply a measure of the state of contraction of the suckers. It is also important to notice that the outer integument is grooved for a little space anteriorly to the appearance of the sucker itself, which suggests a confirmation of a view already put forward, and that is the independence of the suckers of the more specialised Tapeworms from the bothria of the Dibothriata. It appears to be possible that this grooving is the persistent trace of the bothrium, upon which the sucker has been added as a subsequent development.

In series of transverse sections through the head there is another feature of the suckers which deserves mention. It is very clear from such sections that the growth of the sucker has taken place in a definite direction.

Although I am unable to give histological details, it is certainly the fact that anteriorly the sucker is in organic connection with the general tissues of the head. There is no break; it begins gradually with a recognisable condensation of tissue marked by its deeper staining with carmine. On the other hand, at the 
posterior end of the sucker its tissues come to an abrupt end, and I invariably found a shallow cavity between the sucker and the medullary tissue of the head. This suggests that the original position of the sucker is more apical and that it is directed upwards - a state of affairs which is actually seen to persist in many species of Tetracotylea.

The orifices of the generative organs are, as already stated, completely unilateral. I have examined pieces of the worm mounted whole, and many series of sections, and find that in every case there is a regular sequence of the apertures which lie upon one side of the body*. These orifices are not conspicuous on examination with a lens, as they are in many Tapeworms, and for two reasons. In the first place, the orifices are actually small, and in the second place, I have never observed thecirrus to protrude. Thus it is necessary to make a microscopical examination in order to detect the genital pores. Apart from microscopic sections, where, of course, it is easy to find the pores, I have only observed them (that is, in pieces of the worm mounted entire) in the wider posterior segments. Here they are seen to lie at just about the middle of the proglottides. The orifices project slightly and are quite circular.

The excretory system of this Tapeworm presents certain unusual features. In transverse sections through some of the middle segments of the body there are four longitudinal canals perfectly obvious in the body and no more than four, unlike, for instance, the genus Oochoristica, with which the present genus has some characters in common. These four tubes are lateral in position, and are all of them at about the same level. It is thus impossible by position to distinguish the dorsal from the ventral excretory canals. The two on each side are at a considerable distance apart. The distance which separates the outer from the inner of the two is about as great as that which separates the outer tube from the nearest margin of the body. The tubes can, however, be differentiated by their size. The outermost of the two excretory canals is not more than one-third of the diameter of the innermost tube. The form is not, however, so small that it can be missed in transverse sections. In the very anterior segments I have noticed a third lateral vessel on each side; and in this region of the body, moreover, the two main tubes have a greater inclination respectively to the dorsal or ventral side. There is an abundant plexus of vessels connected with these and traversing the proglottides, but I am unable to give details. I think, however, that I have seen numerous external pores.

The testes have a somewhat peculiar arrangement, which is distinctive of this worm. The bulk of these very numerous gonads lie upon that side of the body upon which the generative

* I cannot determine whether this is right or left with certainty, since in transverse sections the gonads are not definitely dorsal or ventral in position, $i$. $e$. nearer to one surface of the proglottid or the other, while the dorsal and ventral excretory tubes are parallel to each other and lie in the same plane with the nerve-cord. 
pores are not situated. They are naturally in the medullary part of the body, and in transverse sections are seen to occupy the greater part of this, being neither dorsal nor ventral in position, but simply central. They reach towards the margin of the segment which is nearest to them, far beyond the outermost of the two excretory tubes of their side of the body - in fact, up to the nerve-cord; medianly they do not reach the median line of the body, but extend beyond the innermost of the two excretory tubes. They occupy perhaps, when seen in this view, one-fourth of the entire breadth of a proglottid. They are not very close together and are, at most, in two rows dorso-ventrally, there being thirteen or fourteen to each row, and thus something like thirty may be visible in a single section. In longitudinal sections seven or eight of these double or partly single rows are seen, and they may be observed to occupy the greater part of the segment. There is also a second set of testes at the opposite margin of the proglottid, very much fewer in number-perhaps four or five in a transverse row, which lie on either side of the outer excretory tube.

The ovary may be regarded as a paired structure, and the two are partly separated by the yolk-gland, which lies between and behind them. In transverse sections through the ovaries, before the other parts of the female reproductive system have been reached, each ovary is seen to be distinct from its fellow and to lie on either side and below the larger of the two excretory tubes, which, in such a section, is seen to be not median in position. The excretory vessel is here only just below the cortical layer of the proglottid, though actually in the medullary layer. The two ovaries are not quite in contact below the vessel, or, at any rate, they can be recognised as two distinct bodies of a bushy form not unlike that which has been figured in other Tapeworms. Within a few sections from that which has served as the basis of the above description the shell-gland is seen taking the place of part of that ovary which lies median of, i.e. not to the pore side of, the excretory vessel, and the oviduct leading from it to the ovary of that side is conspicuous. In a section or so further on in the series the yolk-gland appears; although, as already said, this gland divides the two ovaries, it does not lie symmetrically with reference to the excretory tube. It lies almost entirely on the median side of this tube but also below it, though it does not extend at all on to the pore side of the excretory vessel. It occupies nearly the whole of the space on the inner median side of the excretory tube that, in previous sections, is occupied by the ovary of that side. In the next proglottid to that whose ovaries and associated glands have just been described, the ovary to the outside reached nearer to the outermost and smaller of the two laterally placed excretory tubes, but without arriving at it. In this case it is important to notice that there was no accessory group of testes lying between the ovary and the outermost of the two excretory vessels such as occur in the proglottid first 
described, and which are referred to elsewhere in the description of this species. Series of longitudinal (sagittal and horizontal) sections brought out the position of the ovaries and their relationship to adjacent glands still more clearly. Such sections also showed that the gonads are quite in the middle of the proglottid, i.e. dorso-ventrally. It should be remarked that the double character of the ovary was not always so strongly marked, and that it sometimes lay entirely upon the pore side of the more median (and larger) excretory vessel. Furthermore, I have also observed the yolk-gland to lie upon the median side of the larger excretory tube as well as upon the pore side. There is thus some variability.

It is, perhaps, noteworthy that the gonads of the pore side, which consist of the ovary, yolk-gland, and the testes, together occupy about the same space as the gonad and testes only, in this case, of the opposite side of the proglottid. The female gonads, at any rate, are visible very early in the body, within twenty segments, I dare say, of the head. Shortly after their commencement the mass of tissue which is to form ovary, yolk-gland, and, as I presume, oviduct, vagina, \&c., is seen very plainly to extend towards the periphery of the proglottid between the two longitudinal excretory vessels, a feature of systematic importance in this group which it is necessary to note. In the sexually mature proglottides the oviduct runs straight from the ovary as a thin-walled delicate tube not easy to see, which is sometimes wider, at least near to its termination, in the ejaculatory apparatus, runs to near the distal termination, and then suddenly narrows into a very fine tube with thick, darkly-stained walls which, after a very short course, again suddenly widens into a long sac which is as wide as the cirrus sac and runs beside it and below in position. This terminal reservoir is laxly surrounded by what appears to be an adventitious sheath of muscular fibres, which have a circular direction and thus appear cut across; they are very obvious through their deep staining. This layer of muscles was sometimes, but not always, observed to commence with the very thin region of the vagina. The wide terminal region of the vagina bends towards the cirrus sac and again becomes narrow, opening in common with the latter into the genital cloaca, which is very short. This genital cloaca is quite distinct from an ingrowth of the outer layer of the body which meets it and forms the actual pore; this has been described in considering the external characters. The cirrus sac, as already implied, is neither wide nor long. The cirrus was never seen in a protruded condition, but always lay a darkly staining rod within the pouch. The vas deferens, directly it leaves the cirrus sac, is thrown into a large and complicated coil, which reaches for a considerable distance into the interior of the body. I think that it ends in a dilated vesicula seminalis above the ovary; there is, in any case, a dilated pouch in this region full of sperm, which does not appear to have anything to do with the female ducts. 
In sections through the posterior segment of the body, the ripe eggs, with their sacs, are seen to occupy the whole of the available space, that being, of course, the medullary region of the proglottid. The segments are, in fact, stuffed full of eggs, and, in accordance with this, their dorso-ventral diameter has somewhat increased, though not to so very great an extent as in some other Tapeworms, for instance, in certain specimens of the Oochoristica described in the present paper. A closer examination of the eggs shows that they are imbedded a few together in a dense and darkly staining

के

Text-fig. 158.

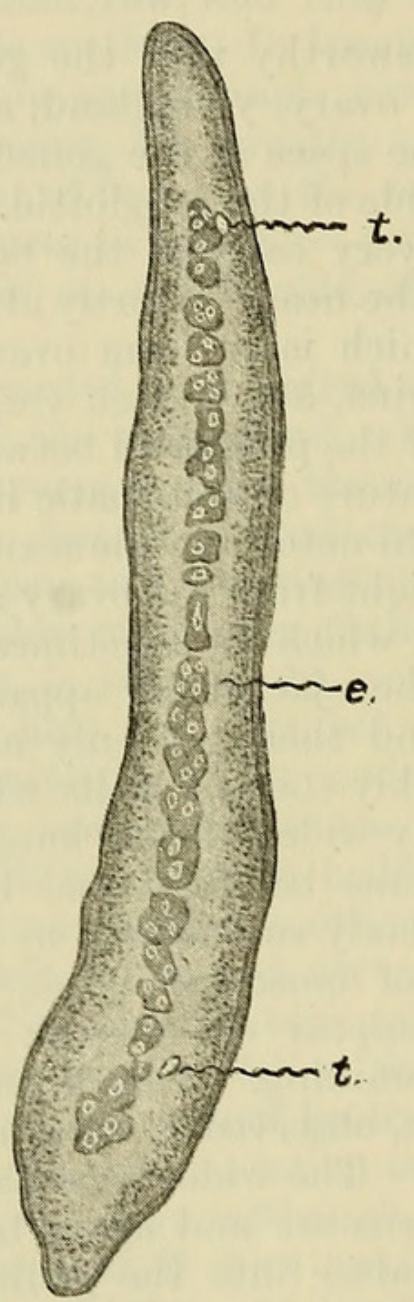

Transverse section through proglottid of Thysanosoma gambianum to show numerous paruterine organs $(e)$. $t$. Water-vessels.

mass of tissue, which closely invests them. These sacs appear to me to be, without doubt, the equivalents of the paruterine organs of many Cestoidea. They are not precisely sacs, in that there is no central lumen occupied by the eggs; they are rather concentrations of the medullary tissue round a series of eggs. These bodies are of approximately equal size and contain much the same number of eggs or, rather, embryos. There is no question here of a circle of paruterine organs surrounding a centrally placed 
uterus. The uterus has entirely vanished, and the paruterine organs are imbedded in the tissues of the body.

\section{Text-fig. 159.}

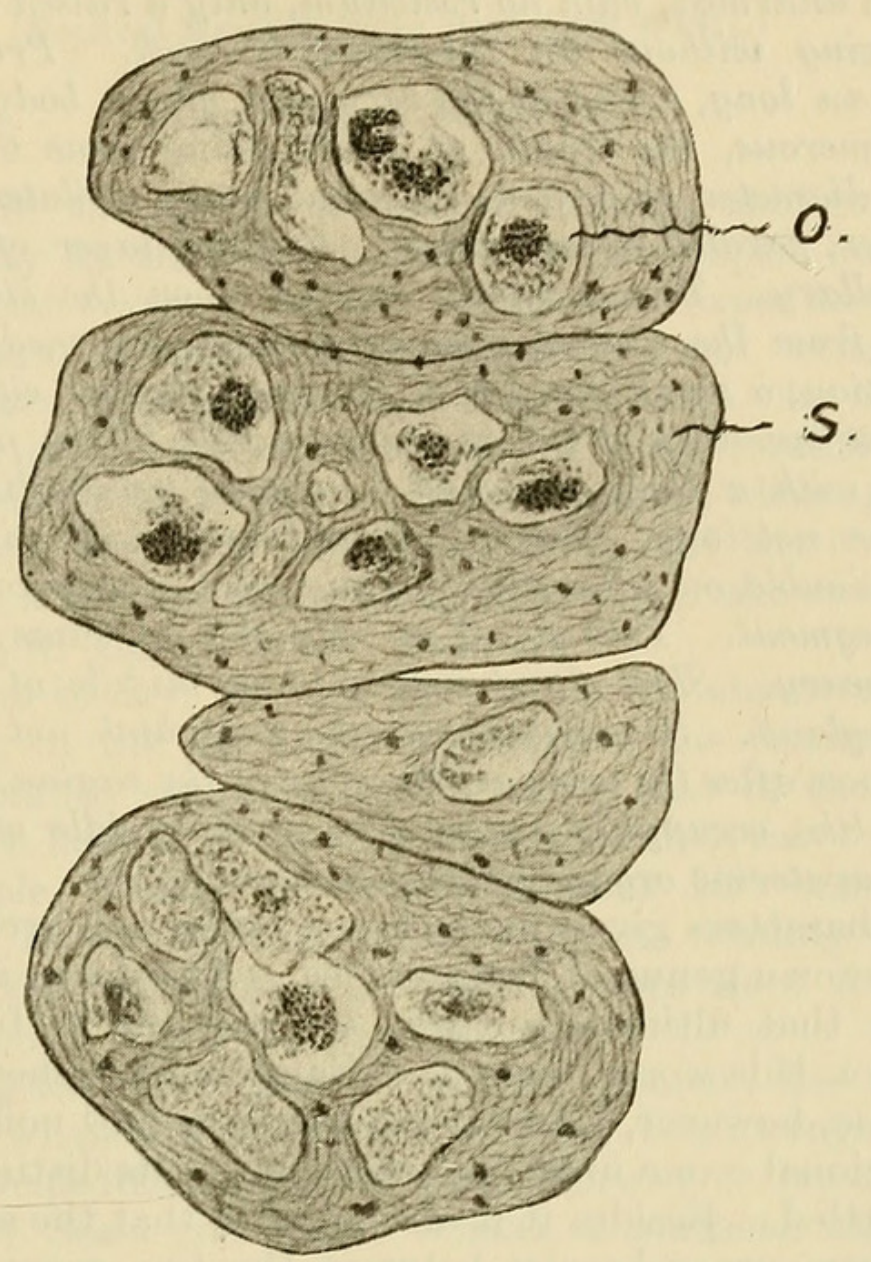

Paruterine organs of Thysanosoma gambianum more highly magnified.
S. Walls of paruterine sacs.
O. Embryos.

So much for the condition in the fully ripe proglottides. Earlier in the body this formation of paruterine sacs is preceded by a uterus which is not very conspicuous, and consists of not much more than a transversely running tube extending nearly right across the proglottid in which the eggs occur, but with which the uterus never appears to be stuffed. I could find no outgrowths of this centrally placed uterus, and there was certainly nothing in the nature of a reticular formation of its cavity. Gradually the cavity of the uterus appeared, as it were, to dry up and the eggs were found - to continue the simile - stranded in the tissue of the body. At this time the formation of the paruterine sacs became visible. Round each egg, or round two or three, as the case might be, the tissue of the medullary region of the proglottid became denser, this being shown by its darker staining. There was thus a concentration of tissue round the ova. This concentration of tissue had no relations that I could detect with the 
uterus. There was nothing like the formation of diverticula of the latter walled by the condensed parenchyma.

The characters of this worm may be briefly summed up as follows :-

Scolex unarmed, with no rostellum, only a raised area. Strobila commencing without an intermerliate neck. Proglottides much wider than long, except at the very end of the body. Proglottides very numerous, the length of worm being some 6 inches with a greatest diameter of $6 \mathrm{~mm}$. Genital pores unilateral. Excretory tubes four, parallel to each other. Cortical layer of body as thick as medullary. Testes chiefly massed upon the side of the body furthest from the genital pore, very numerous, median in position. In addition, a small number of similar testes on either side of the outermost excretory vessel of the pore side of the proglottid. Vas deferens with a large coil and a vesicula seminalis above ovary; cirrus sac not long. Genital cloaca small, with circular muscles. Ovaries double, on either side of innermost of excretory tubes of pore side of segment. Yolk-gland on one side of same excretory vessel behind ovary. Shell-gland nearer to the middle of the body above the yolk-gland. Seminal receptacle, long and not much swollen, begins soon after the terminal chamber of the vagina. Uterus hroad and sac-like, occupying a great deal of the middle of the proglottid. Many paruterine organs present in later stages.

The characters given in the above paragraph are not distinctive of any known genus of Tetracotylea. And I am, indeed, disposed to think that ultimately it will be necessary to form a separate genus for this worm from the Gambian Pouched Rat. In the meantime, however, I do not burden zoological nomenclature with an additional name until the possibility of its distinctness becomes more settled. Besides it is also possible that the existence of this species remaves a barrier between the two genera Thysanosoma and Anoplocephala. Until I had become aware of the numerous paruterine organs, I was disposed to refer the worm to Anoplocephala, with which genus it obviously has many points in common. But the existence of these characteristic paruterine organs-and in such great numbers - is a reason for removing it from Anoplocephala and uniting it with Thysanosoma. On the other hand, the latter genus has either double or single sets of generative organs, and, correspondingly, either two pores upon each proglottid or alternating pores, while the Tetracotylean described in the foregoing pages has generative pores all upon one side. Nevertheless, the double set of testes seems to be a last trace of an originally completely double set of gonads and ducts, such as occurs in some proglottides of other Thysanosomas. If the small set of the testes existing in this species upon the pore side of the ovaries were to disappear it would be, as I think, impossible to separate this genus from Anoplocephala or Zschokkeella; but the definition of those genera would have to be enlarged in order to take in the numerous paruterine organs, which is, after all, perhaps the chief reason for referring this worm to the subfamily Thysanosominæ which is mainly thus characterised. 


\section{$2 \mathrm{BHL}$ Biodiversity Heritage Library}

Beddard, Frank E. 1911. "Contributions to the anatomy and systematic arrangement of the Cestoidea. I. On some mammalian Cestoidea." Proceedings of the Zoological Society of London 1911, 626-660. https://doi.org/10.1111/j.1096-3642.1911.tb01951.x.

View This Item Online: $\underline{\text { https://www.biodiversitylibrary.org/item/98513 }}$

DOI: https://doi.org/10.1111/j.1096-3642.1911.tb01951.x

Permalink: https://www.biodiversitylibrary.org/partpdf/70001

\section{Holding Institution}

Smithsonian Libraries

\section{Sponsored by}

Biodiversity Heritage Library

\section{Copyright \& Reuse}

Copyright Status: Public domain. The BHL considers that this work is no longer under copyright protection.

This document was created from content at the Biodiversity Heritage Library, the world's largest open access digital library for biodiversity literature and archives. Visit BHL at https://www.biodiversitylibrary.org. 